\title{
Growth of larval walleye pollock related to domains within the SE Bering Sea
}

\author{
Paul D. Walline \\ Israel Oceanographic and Limnological Research, POB 8030, Haifa, Israel
}

\begin{abstract}
The relation between growth rates of larval walleye pollock Theragra chalcogramma and the frontal system within the SE Bering Sea was investigated. Growth rates were determined by enumerating daily growth increments on the otoliths of larval pollock collected from various areas within the Bering Sea in 1978 and 1979. Growth rates were constant with length for 1066 larvae from 4 to $25 \mathrm{~mm}$ standard length (SL), and averaged $0.35 \mathrm{~mm} \mathrm{~d}^{-1}$ Differences in growth rates of larvae from separate oceanographic domains, years and areas were small, although statistically significant. Based on growth rates, no starving larvae were found, and no interval in time was especially favorable for their survival. It was concluded that food was abundant enough to allow survival of first-feeding larval pollock during a long period of time over a wide area of the Bering Sea in 1979.
\end{abstract}

\section{INTRODUCTION}

A study of the ecosystem of the SE Bering Sea shelf, PROBES (Processes and Resources of the Bering Sea Shelf) began in 1977. Because there is an important fishery for walleye pollock Theragra chalcogramma, it was chosen as a biological tracer, or indicator, of the processes which account for the apparent high productivity of upper trophic levels in the Bering Sea. As preliminary results became available, PROBES scientists developed an hypothesis relating survival of pollock larvae to wind mixing and food concentration, suggesting a mechanism, similar to that described by Lasker (1975) for anchovy, which could cause variations in survival (Cooney et al., 1978). At 6 to $7^{\circ} \mathrm{C}$, larval pollock hatch at a length of 3.5 to $4.4 \mathrm{~mm}$ and complete yolk-sac absorption at a length of 4.8 to 6.5 $\mathrm{mm}, 11 \mathrm{~d}$ later (Yusa, 1954). It is during this period that larvae begin feeding. It was hypothesized that when this stage coincides with periods of calm weather, reduced wind mixing of the surface layer would allow growth or concentration of microplankton needed by these first-feeding larvae. Larvae would survive in greater numbers during those times, and year-class strength would depend on the number and duration of those intervals. This hypothesis was tested in the present investigation by examining the distribution of hatching dates of larvae, which survived the critical period of first feeding, to detect periods of high and low survival.

A major result of the PROBES study was the discovery of 3 fronts in the SE Bering Sea which divide the shelf into 4 regions: Oceanic Domain, Outer Shelf Domain, Middle Shelf Domain and Coastal Domain (Fig. 1). The fronts are related to depth contours and persist in the same approximate locations year round (Kinder and Coachman, 1978). The frontal system has been shown to be of ecological significance by Iverson et al. (1979) who related the distribution of plankton, birds, fishes and benthos to the domains. In the present study the relationship between growth rates and

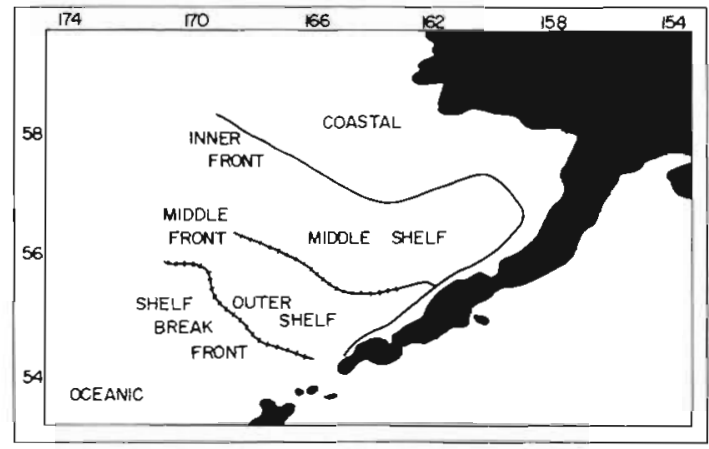

Fig. 1. Oceanic, Outer Shelf, Middle Shelf, and Coastal Domains of the eastern Bering Sea. (After Kinder and Schumacher, 1981) 
domains was examined to identify areas and conditions especially favorable for the growth and survival of larval pollock.

The use of growth rate to investigate survival depends on the assumption that survival is closely related to growth. If larvae are starving, the relation is clear. However, even if larvae are not starving, a reduced growth rate can result in increased mortality, mainly by increasing predation, but also by increasing sensitivity to toxic substances, $\mathrm{pH}$, or low dissolved oxygen (Ivlev, 1961). There is evidence that the growth of fishes is sensitive to environmental factors such as available food (Edwards et al., 1970; Paloheimo and Dickie, 1970; Laurence, 1977), temperature (Kinne, 1960), and fish density (Illes, 1968). Since the effects of such factors should be most easily observed during the first year when specific growth rates are high, it was assumed that larvae which were starving would show reduced growth rates. Thus, measurement of apparent growth rates allows one to make inferences about variations in survival. In addition, if year-class strength is determined during the larval stage, as is thought to be the case for many fish (Blaxter, 1974), larval growth rates may be useful in helping to predict recruitment.

The age of some larval fish can be determined by enumerating growth increments which appear on the otoliths (e.g. Panella, 1971; Campana and Neilson, 1982; Ralston and Miyamoto, 1983). Although otolith rings apparently do not always reliably indicate age for all species (Geffen, 1982), several species closely related to pollock do form daily increments (Brothers et al, 1976; Radtke and Waiwood, 1980). It was assumed in the present study that the increments observed in the otoliths of larval pollock also form daily. In addition, Marshall and Parker (1982) reported that daily increment formation in otoliths of salmon continues even during periods of starvation lasting up to 2 weeks, so the method should be applicable to larvae growing at low rates.

\section{MATERIALS AND METHODS}

In 1978 preliminary samples for determination of age and growth were collected from the RV 'Thomas G. Thompson' (Fig. 2). Four double oblique tows to $50 \mathrm{~m}$ depth were made with a $60 \mathrm{~cm}$ bongo net with $0.505 \mathrm{~mm}$ mesh (McGowan and Brown, 1966), and the remaining sample was taken with a $1.3 \mathrm{~m}$ ring net $10.505 \mathrm{~mm}$ mesh) retrieved from a depth of $70 \mathrm{~m}$

Most of the pollock larvae for this study were collected from the Bering Sea on a cruise of RV Miller Freeman' from 1 June to 23 July 1979 (Table 1). Pollock larvae were defined as pollock shorter than $25 \mathrm{~mm} \mathrm{SL}$, the approximate length at which pollock complete fin ray development and become juveniles (Haryu, 1980).

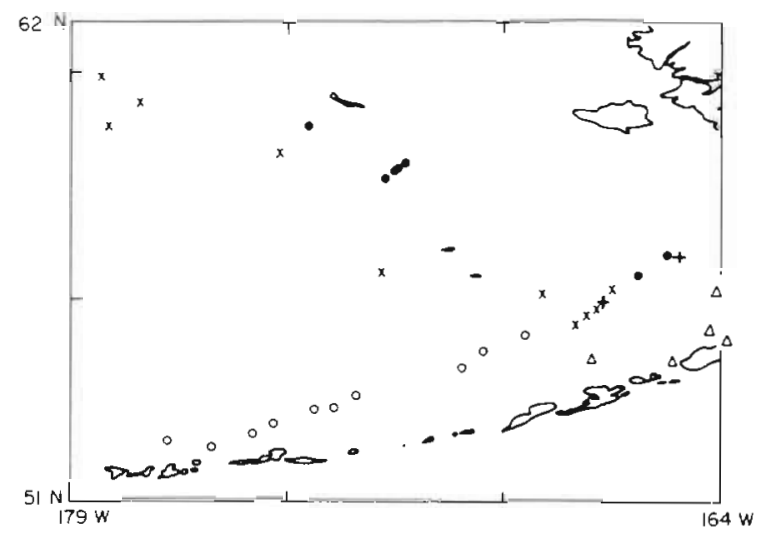

Fig. 2. Theragra chalcogramma. Locations where pollock larvae were obtained by domain and year. Oceanic Domain, 1979 (O); Outer Shelf Domain, 1979 (x): Middle Shelf Domain, $1979(\bullet)$; Outer Shelf Domain, $1978(\Delta)$; and locations sampled over a 48 -h period $(+)$

On the 1979 cruise of RV 'Miller Freeman', at least 1 CTD cast for temperature, depth, and salinity was made at nearly every station. A neuston net, a bongo net, and a Tucker trawl were hauled following standard procedures as described by Smith and Richardson (1977).

Two representative stations were selected near the center of the spawning grounds of walleye pollock within the eastern Bering Sea. These 2 stations were also near the center of the distribution of eggs and larvae of pollock determined in previous surveys (Waldron, 1981). At these stations a series of samples was taken every 6 h over a $48 \mathrm{~h}$ period. Most of the samples and larvae were obtained at these 2 locations, which were in the Outer Shelf Domain and the Middle Shelf Domain, respectively (Fig. 2). Sampling at all other sites was carried out only at night, thus reducing avoidance and allowing the direct comparison of catches. All comparisons of densities were made on the basis of bongo hauls taken at night.

Pollock larvae were sorted at sea from each $0.505 \mathrm{~mm}$ mesh bongo sample and from each Tucker trawl haul. The larvae sorted from samples at sea were preserved in $80 \%$ ethanol which was replaced after $24 \mathrm{~h}$. Ethanol was used as a preservative to prevent dissolution of otoliths (Methot and Kramer, 1979), and to reduce variations in shrinkage of larvae. Shrinkage in formalin can be variable depending on the time between death and fixation and the length of time the larvae are preserved. Variations in length of time between death and fixation occur because some larvae die in the net while others remain alive until fixed. Including sorting time, the range in length of time between death and fixation may be up to $25 \mathrm{~min}$ for a bongo tow. However, Radtke and Waiwood (1980) found that after $74 \mathrm{~d}$ of preservation in ethanol, Atlantic cod larvae fixed alive 
Table 1. Theragra chalcogramma. Larval pollock collection, 1978-1979: station number, date, location, number, average standard length, average growth rate and standard deviation (SD)

\begin{tabular}{|c|c|c|c|c|c|c|c|c|c|}
\hline \multirow{2}{*}{$\begin{array}{l}\text { Stn } \\
\text { no. }\end{array}$} & \multirow[t]{2}{*}{ Date } & \multicolumn{2}{|c|}{ N Lat } & \multicolumn{2}{|c|}{ W Long } & \multirow{2}{*}{$\begin{array}{l}\text { No. } \\
\text { of } \\
\text { fish }\end{array}$} & \multirow{2}{*}{$\begin{array}{c}\text { Average } \\
\text { length } \\
(\mathrm{mm})\end{array}$} & \multicolumn{2}{|c|}{$\begin{array}{c}\text { Average } \\
\text { growth rate }\end{array}$} \\
\hline & & $(\mathrm{deg})$ & $(\min )$ & (deg) & $(\min )$ & & & $\left(\mathrm{mm} \mathrm{d}^{-1}\right)$ & $(\mathrm{SD})$ \\
\hline 2001 & 7 May 1978 & 54 & 52.3 & 167 & 8.4 & 1 & 10.2 & 0.17 & - \\
\hline 4001 & 17 Jun 1978 & 54 & 36.1 & 165 & 10.2 & 5 & 20.4 & 0.30 & 0.01 \\
\hline 4013 & 20 Jun 1978 & 56 & 4.9 & 164 & 7.2 & 3 & 10.8 & 0.26 & 0.02 \\
\hline 5008 & 4 Jul 1978 & 55 & 25.6 & 164 & 13.5 & 21 & 16.6 & 0.29 & 0.05 \\
\hline 5018 & 7 Jul 1978 & 55 & 17.2 & 163 & 33.0 & 1 & 23.8 & 0.36 & - \\
\hline$V_{01}{ }^{\circ}$ & 2 Jun 1979 & 56 & 3.1 & 166 & 34.2 & 320 & 17.1 & 0.38 & 0.04 \\
\hline v02" & 4 Jun 1979 & 57 & 3.0 & 165 & 2.0 & 570 & 7.8 & 0.49 & 0.12 \\
\hline $\mathrm{S} 07$ & 1 Jun 1979 & 55 & 26.8 & 167 & 18.4 & 3 & 18.3 & 0.36 & 0.01 \\
\hline S08 & $1 J_{u n} 1979$ & 55 & 39.3 & 167 & 3.9 & 14 & 17.7 & 0.36 & 0.02 \\
\hline sog & 2 Jun 1979 & 55 & 51.0 & 166 & 33.8 & 3 & 19.0 & 0.40 & 0.04 \\
\hline S11 & 6 Jun 1979 & 57 & 5.2 & 165 & 15.4 & 21 & 13.8 & 0.41 & 0.06 \\
\hline $\mathrm{S} 12$ & 6 Jun 1979 & 56 & 34.9 & 165 & 54.6 & 22 & 20.6 & 0.42 & 0.03 \\
\hline $\mathrm{S} 13$ & 6 Jun 1979 & 55 & 10.2 & 168 & 28.3 & 11 & 196 & 0.40 & 0.04 \\
\hline $\mathrm{S} 14$ & 7 Jun 1979 & 54 & 48.0 & 169 & 28.0 & 1 & 14.5 & 0.40 & - \\
\hline $\mathrm{S} 17$ & 7 Jun 1979 & 53 & 41.3 & 172 & 28.8 & 1 & 17.1 & 0.36 & - \\
\hline $\mathrm{S} 18$ & 7 Jun 1979 & 53 & 20.9 & 173 & 23.4 & 6 & 15.8 & 0.35 & 0.03 \\
\hline S19 & 8 Jun 1979 & 53 & 0.8 & 174 & 19.4 & 7 & 16.0 & 0.35 & 0.04 \\
\hline $\mathrm{S} 21$ & 16 Jun 1979 & 52 & 2.9 & 175 & 43.4 & 1 & 13.6 & 0.33 & - \\
\hline $\mathrm{S} 22$ & 16 Jun 1979 & 52 & 45.6 & 174 & 48.5 & 2 & 15.9 & 0.31 & - \\
\hline $\mathrm{S} 24$ & 16 Jun 1979 & 53 & 26.0 & 172 & 53.8 & 2 & 16.6 & 0.29 & - \\
\hline $\mathrm{S} 26$ & 17 Jun 1979 & 54 & 25.8 & 169 & 55.3 & 1 & 21.7 & 0.36 & - \\
\hline S33 & 19 Jun 1979 & 56 & 16.2 & 166 & 29.6 & 1 & 24.5 & 0.37 & - \\
\hline $\mathrm{S} 41$ & 22 Jun 1979 & 56 & 10.9 & 168 & 5.2 & 1 & 20.9 & 0.37 & - \\
\hline S63 & 28 Jun 1979 & 56 & 39.4 & 171 & 47.2 & 1 & 23.9 & 0.42 & - \\
\hline $\mathrm{S} 71$ & $1 \mathrm{Jul} 1979$ & 52 & 33.2 & 176 & 44.5 & 1 & 20.6 & 0.36 & - \\
\hline $\mathrm{S} 101$ & $16 \mathrm{Jul} 1979$ & 58 & 45.9 & 171 & 46.5 & 2 & 13.0 & 0.28 & - \\
\hline $\mathrm{S} 102$ & $16 \mathrm{Jul} 1979$ & 58 & 58.4 & 171 & 26.5 & 6 & 12.9 & 0.30 & 0.02 \\
\hline S103 & 16 Jul 1979 & 59 & 7.7 & 171 & 5.7 & 3 & 13.7 & 0.30 & 0.05 \\
\hline $\mathrm{S} 104$ & 16 Jul 1979 & 58 & 58.0 & 171 & 26.6 & 17 & 11.2 & 0.31 & 0.06 \\
\hline $\mathrm{S} 110$ & 19 Jul 1979 & 59 & 19.2 & 174 & 10.7 & 3 & 9.5 & 0.36 & 0.09 \\
\hline $\mathrm{S} 112$ & $20 \mathrm{Jul} 1979$ & 59 & 49.4 & 173 & 34.2 & 1 & 15.5 & 0.34 & - \\
\hline S115 & $21 \mathrm{Jul} 1979$ & 59 & 50.7 & 178 & 8.9 & 3 & 11.1 & 0.32 & 0.04 \\
\hline S116 & 22 Jul 1979 & 60 & 22.2 & 177 & 25.5 & 3 & 10.5 & 0.34 & 0.09 \\
\hline $\mathrm{S} 117$ & 23 Jul 1979 & 60 & 54.4 & 178 & 16.7 & 8 & 12.9 & 0.31 & 0.02 \\
\hline
\end{tabular}

showed no difference in measured length from larvae fixed $15 \mathrm{~min}$ after death. Since in the present study larvae were examined after $75 \mathrm{~d}$ preservation in ethanol, problems of variable shrinkage have been minimized.

In the laboratory larvae were processed using the method of Brothers et al. (1976) with modifications developed by Methot and Kramer (1979). In brief, the SL of each larva was measured and the sagittae removed and placed flat side up on a microscope slide. Since the lapillae for larvae less than $8 \mathrm{~mm}$ SL were nearly the same size as the sagittae, in most cases all 4 otoliths were removed and mounted. The use of a polarizing filter and analyser on the dissecting micro- scope made it easier to remove the otoliths, some of which were as small as $20 \mu \mathrm{m}$. After drying, the otoliths of larvae shorter than $20 \mathrm{~mm}$ SL were mounted in Protexx (Lerner Laboratory, Stamford, Conn.), a clear mounting medium. Otoliths from larger larvae were mounted in drops of polyester resin. Those mounts allowed larger otoliths to be ground on fine sandpaper, polished with $0.3 \mu \mathrm{m}$ alumina, and etched with drops of $0.1 \mathrm{~N} \mathrm{HCl}$. This procedure was necessary to clear otoliths enough to count all increments. Increments were more easily distinguished and accuracy of counts was improved by using a video camera to project the image from the $100 \mathrm{X}$ or $40 \mathrm{X}$ objective onto a video screen. Counts were repeated until successive counts differed 
by fewer than 3 increments. When both otoliths were counted, the values were averaged.

All otolith preparations were labelled only with a code number, so that when making a count, I was not aware of the SL of the larvae or the results of any previous counts. To assess the precision of counts, 39 otoliths were selected using a table of random numbers, and the daily growth increments were enumerated again. The new count and the original count were used to calculate an estimate of the coefficient of variation, and the 39 separate estimates were averaged.

To determine how many days after hatching the first increment forms, larvae of known age were obtained. Eggs were collected from the sea on the 1978 PROBES cruise of the RV 'Thomas G. Thompson' and incubated. Each day's hatch was transferred to a separate container of seawater treated with antibiotics to retard bacterial growth. The containers were kept on deck in a bath of seawater pumped from near the surface. After a period of a few days, all the larvae in a container were killed and preserved in $80 \%$ ethanol

An average growth rate for each larvae was calculated from:

$$
\mathrm{GR}=(\mathrm{SL}-4) / \mathrm{AGE}
$$

where $\mathrm{GR}=$ average growth rate in $\mathrm{mm} \mathrm{d}^{-1} ; \mathrm{SL}=$ standard length in $\mathrm{mm}$; $\mathrm{AGE}=$ age in days after hatching; $4 \mathrm{~mm}=$ estimated length at hatching. The slope of a plot of SL against number of increments is also an estimate of average growth rate, provided that the growth curve is linear and that each increment represents one day of age (Fig. 3). Growth rates were obtained from the slopes of lines fitted by least squares regression analysis and were compared between samples or groups of samples using an analysis of covariance.

The age in days of each larva was used with the date of the sample to back-calculate the date of hatching. The age of each larvae, equal to the number of increments plus the number of days between hatching and the formation of the first increment, was subtracted from the date of sampling to obtain the date of hatching

\section{RESULTS}

At the 48 h locations, Stations V01 ad V02, densities of larval pollock were among the highest observed, 12 and $14 \mathrm{~m}^{-2}$, respectively. The highest density $\left(21 \mathrm{~m}^{-2}\right)$ of larval pollock during the 1979 RV 'Miller Freeman' cruise was found at a station near the center of Bristol Bay, in the Middle Shelf Domain. These results support the conclusion that Stations V01 and V02 were located in the major spawning grounds for walleye pollock in the southeastem Bering Sea, as expected from previ-

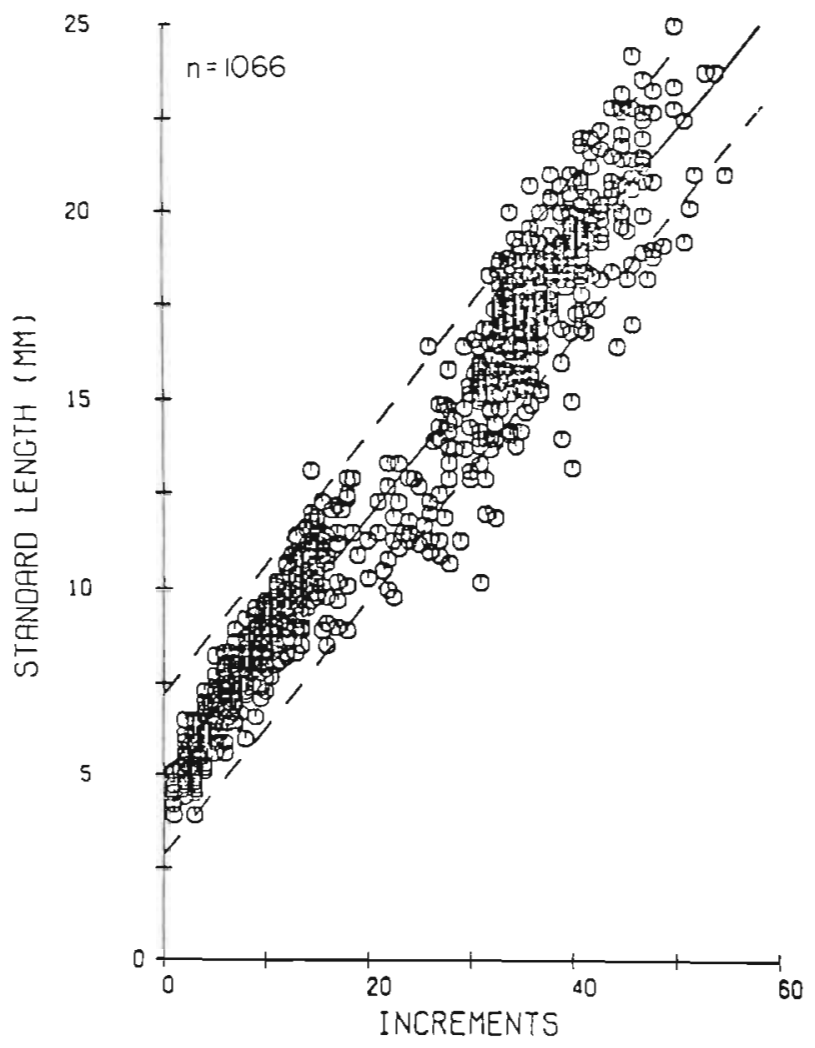

Fig. 3. Theragra chalcogramma. Standard length related to daily growth increments on otoliths of pollock larvae for all data combined. The line fitted by least squares regression analysis is shown with the $95 \%$ confidence interval for standard length predicted from the number of increments

ous surveys (Waldron, 1981). However, the occurrence of a few pollock larvae $\left(0.7\right.$ to $\left.5.8 \mathrm{~m}^{-2}\right)$ at deep water locations and in areas north of the Pribilof Islands, far from the presumed location of spawning (Smith, 1981), was unexpected and remains unexplained. Most of these larvae caught in the Oceanic Domain could not have drifted from the Outer or Middle Shelf Domains because the mean circulation is sluggish (1 to $10 \mathrm{~cm} \mathrm{~s}^{-1}$ ) and flow is generally to the northwest along isobaths (Kinder and Coachman, 1978).

In 1979,136 salinity and temperature casts were made. Temperatures in the upper mixed layer, where most of the larvae were caught, ranged from $6^{\circ} \mathrm{C}$ to just over $8^{\circ} \mathrm{C}$. The upper mixed layer extended to a depth of about $20 \mathrm{~m}$ at Stations V01 and V02, sampled for $48 \mathrm{~h}$ each. At stations north of the Pribilof Islands, the upper mixed layer was almost $50 \mathrm{~m}$ deep and the surface temperature was slightly higher than $8^{\circ} \mathrm{C}$.

Counts were made of daily increments for 23 larvae of known age. Although the otoliths of reared larvae showed only faint and narrow increments, the number of increments observed increased with the age of the reared larvae. The time for the formation of the first 
increment ranged from 0 to $6 \mathrm{~d}$ after hatching, with an average of $3.2 \mathrm{~d}$.

Otoliths of field-caught larvae varied widely in ease of interpretation, but faint, indistinct increments like those of the reared larvae were not observed. Most otoliths had opaque sectors which obscured increments, while increments on other sectors of the same otoliths were very clear. Therefore, the appearance of opaque areas on an otolith was not considered indicative of starvation, even if so much of the otolith was obscured that a count was not possible. For otoliths which could be read, counting errors were low. The coefficient of variation for increment counts was $4 \%$, corresponding to a $95 \%$ confidence interval of \pm 2 increments for a single count of 25 increments.

Ages were obtained from otoliths for 1066 larvae. Growth rates calculated using Eq. (1) ranged from $0.17 \mathrm{~mm} \mathrm{~d}^{-1}(\mathrm{n}=1)$ at Station 2001, 7 May 1978, to $0.49 \mathrm{~mm} \mathrm{~d}^{-1}$ (n = 570) at Station V02, 5 June 1979 (Table 1).

Average growth rates for domains were obtained by averaging the growth rates calculated for each location (Table 2). Thus, Stations V01 and V02, with hundreds of larvae sampled, were not over-represented. Differences between average growth rates calculated using Eq. (1) were not tested for significance.

Table 2. Theragra chalcogramma. Average growth rates (GR) by domain, from Eq. (1) and from slope of lines fitted to plots of SL against number of increments

\begin{tabular}{|cccccc|}
\hline Year & Domain & $\begin{array}{c}\text { Number } \\
\text { of } \\
\text { locations }\end{array}$ & $\begin{array}{c}\text { Number } \\
\text { of } \\
\text { larvae }\end{array}$ & $\begin{array}{c}\text { GR } \\
\text { (Eq 1) }\end{array}$ & $\begin{array}{c}\text { GR } \\
\text { (slope) }\end{array}$ \\
\hline 1978 & Outer & 5 & 31 & 0.28 & 0.30 \\
1979 & Oceanic & 10 & 33 & 0.35 & 0.34 \\
& $\begin{array}{c}\text { Outer } \\
\text { Middle } \\
\text { north } \\
\text { south } \\
\text { all }\end{array}$ & 11 & 360 & 0.36 & 0.35 \\
& $\underline{3}$ & $\underline{613}$ & $\underline{0.44}$ & $\underline{0.39}$ \\
Middle & 8 & 642 & 0.36 & 0.37 \\
\hline
\end{tabular}

In 1979 pollock larvae were caught in the Oceanic, Outer Shelf, and Middle Shelf Domains. The Coastal Domain was not sampled. Larvae from the 3 domains were found to have similar growth rates (Fig. 4), although in the cases cited below the differences were statistically significant $(p<0.05)$. These results are derived from large sample numbers, and in absolute terms, the differences between inferred growth rates from different domains were small (Table 2). For example, pollock larvae grew slightly faster in the Middle Shelf Domain $\left(0.37 \mathrm{~mm} \mathrm{~d}^{-1}\right)$ than in the Outer
A
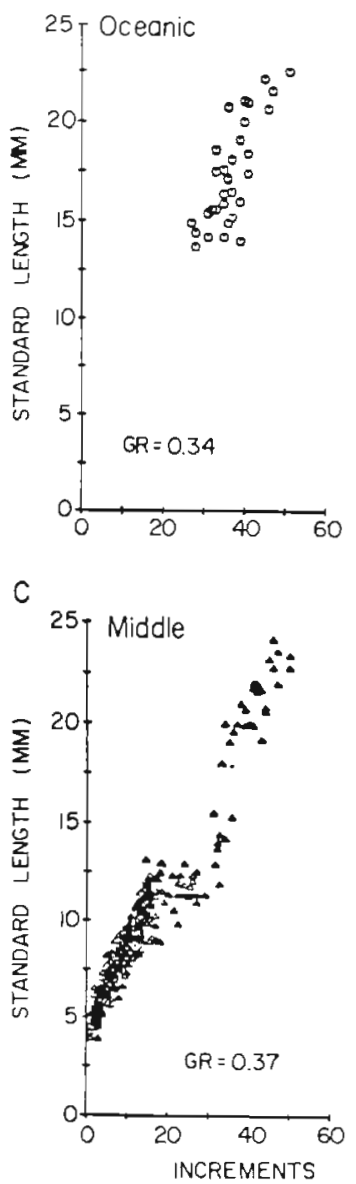

8

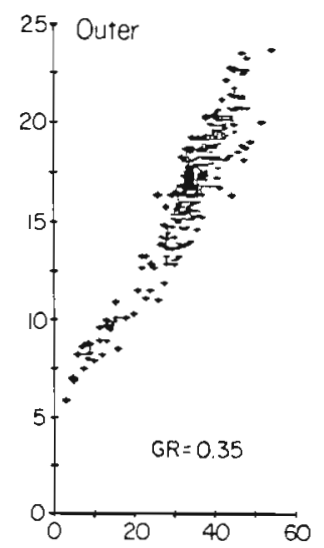

D

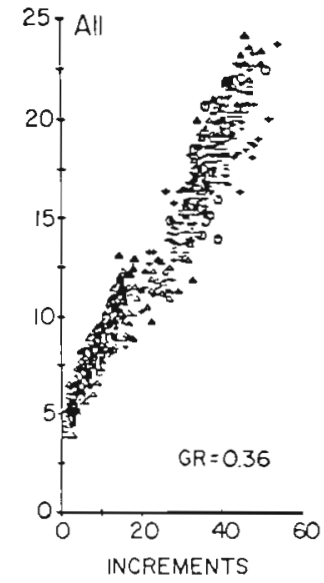

Fig. 4. Theragra chalcogramma. Standard length related to daily growth increments on otoliths of pollock caught during 1979 RV 'Miller Freeman' cruise in (A) Oceanic Domain, (B) Outer Shelf Domain, (C) Middle Shelf Domain, (D) all domains combined. In each case, $G R$ is the growth rate estimated from the slope of the regression line, forced through the point $5 \mathrm{~mm}$ at 0 increments

Shelf Domain (0.35 $\left.\mathrm{mm} \mathrm{d}^{-1}\right)$ or the Oceanic Domain (0.34 $\left.\mathrm{mm} \mathrm{d}^{-1}\right)$. Within the Middle Shelf Domain, larvae from samples taken in July far to the north of the center of distribution grew more slowly $10.32 \mathrm{~mm} \mathrm{~d}^{-1} \mathrm{com}-$ pared to $0.39 \mathrm{~mm} \mathrm{~d}^{-1}$ ), but slower growth was not observed for northern areas within the Outer Shelf Domain.

In 1978 samples were taken from the Outer Domain only. Growth within that domain averaged $0.30 \mathrm{~mm}$ $\mathrm{d}^{-1}$ and $0.35 \mathrm{~mm} \mathrm{~d}^{-1}$ in 1978 and 1979, respectively. Larvae averaged nearly the same length in samples from the two years, $16.7 \mathrm{~mm}$ (1978) and $16.9 \mathrm{~mm}$ (1979).

When the distribution of hatching dates is calculated for all pollock taken on the 1979 RV 'Miller Freeman' cruise in all nets at all stations, it is heavily influenced by the large number of hauls made at the 2 locations sampled for $48 \mathrm{~h}$ each. To avoid this bias, each station was represented by a single bongo haul, all taken at 
night. Hatching dates calculated in this way were distributed from 1 April to 15 July, with most occurring from mid-April to mid-May (Fig. 5).

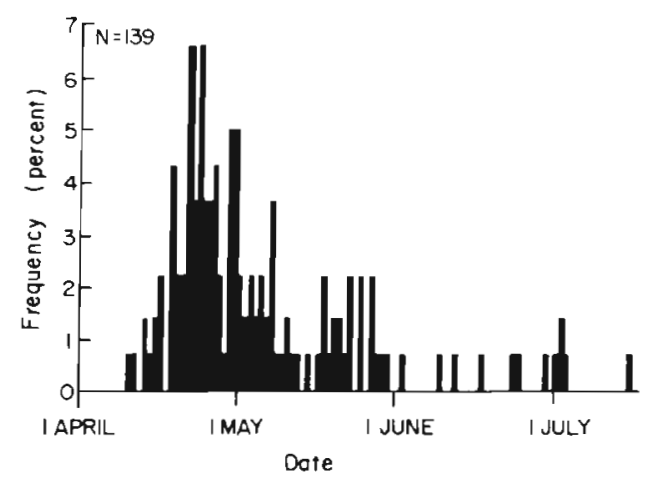

Fig. 5. Theragra chalcogramma. Frequency to date of hatching, expressed as a percentage of all pollock caught in one $0.505 \mathrm{~mm}$ mesh bongo net haul from each location, 1 June to 23 July 1979

\section{DISCUSSION}

To my knowledge, this is the first measurement of larval pollock growth rates in the sea using the daily growth increment method. There are a few other estimates of the growth rate of larval pollock which can be compared with those reported here. Cooney et al. (1978) calculated growth rates from length-frequency distributions, finding growth rates of larvae $10 \mathrm{~mm} \mathrm{SL}$ to be as low as $0.10 \mathrm{~mm} \mathrm{~d}^{-1}$. In the laboratory even lower growth rates have been observed (Hamai et al, 1971, 1974). The larvae in the studies of Hamai et al. died after $1 \mathrm{mo}$, having grown only $0.5 \mathrm{~mm}$. Since none of the 1066 larvae I examined had a growth rate as low as $0.10 \mathrm{~mm} \mathrm{~d}^{-1}$, it appears that none was starving. Thus, predation may have been more important than starvation in reducing larval numbers.

In 1979 average growth rates of larval pollock were surprisingly uniform over wide areas and long periods encompassing very different environmental conditions. Even the larvae from far out in the Oceanic Domain (Stations S17, S18, and S19, for example) were growing at nearly average rates (Fig. 4). Pollock larvae have not been previously reported to occur in these areas, and their origin is unclear. They may be the spawn of the pollock population reported to be dispersed in the Aleutian Basin of the Bering Sea (Okada, 1978). In any case, these larvae appear to be able to survive and grow rapidly in open ocean waters, far from the center of distribution of pollock eggs and larvae.

Although a difference in growth rates was detected between the Middle and Outer Shelf Domains of the SE Bering Sea, a larger difference was expected because the Middle and Outer Shelf Domains have quite different populations of copepods (Cooney and Coyle, 1982), the main food item of larval pollock (Clarke, 1978). A somewhat larger difference was noted within the Middle Shelf Domain (Table 2). In this domain larvae from the north of the Pribilof Islands appeared to grow slower by $0.10 \mathrm{~mm} \mathrm{~d}^{-1}$ than larvae from farther south. Since temperatures were similar, and in fact slightly higher at the more northerly locations, the reduced growth rate might be explained by the deeper mixed layer and resulting lower food concentrations at the more northerly locations. By comparison to these small differences, average growth rates of individual larvae differed by $0.40 \mathrm{~mm} \mathrm{~d}^{-1}$ within some locations.

The years 1978 and 1979 were quite similar in average sea surface temperature, in percentage ice cover, and in average wind speed (Niebauer, 1980), and larval growth rates were nearly identical, differing only by $0.05 \mathrm{~mm} \mathrm{~d}^{-1}$. If growth rates of larvae were closely related to the strength of the resulting year-class, the 1978 and 1979 year-classes should have been of nearly equal strength. In fact, if the difference in growth rates observed was enough to have had any effect, the 1979 year-class should have been stronger than that of 1978 . However, indications are that the 1978 year-class was stronger than average and the 1979 class much weaker than average (Bakkala and Wespestad, 1982). It is possible that pollock year-class strength is controlled after the larval period, and in that case no relation between larval growth rates and year-class strength would be expected.

Although the distribution of estimated hatching dates is sensitive to net selectivity, sample distribution in time and space, errors in determining the time of first increment formation, errors in counting increments, shrinkage of larvae on preservation, and other factors, the distribution of dates calculated for 1979 nevertheless indicates that successful first feeding was not dependent on time (Fig. 5). Hatching times of larvae which survived the time of first feeding were distributed throughout the spawning period.

Acknowledgements. This manuscript is based on part of a doctoral dissertation submitted at the University of Washington, under the supervision of $T$. Saunders English. The research was funded in part by a PROBES (NSF) contract to $T$ Saunders English, and was completed while the author held a NOAA Graduate Student Appointment at the Northwest and Alaska Fisheries Center, Seattle, Wash. (USA).

I gratefully acknowledge the help and advice given to me by T. Saunders English and Art W. Kendall, Jr. I also thank T. Berman for comments and criticisms.

\section{LITERATURE CITED}

Bakkala, R., Wespestad, V (1982). Pollock. In: Bakkala, R., Low, L. (ed.) Condition of groundfish resources of the eastern Bering Sea and Aleutian Islands region in 1982 
Unpubl. Rep., Northwest and Alaska Fisheries Center, National Marine Fisheries Service, NOAA, Seattle, p. $1-28$

Blaxter, J. H. S. (ed.) (1974). The early life history of fish. Springer-Verlag, Berlin

Brothers, E. B., Matthews, C. P., Lasker, R. (1976). Daily growth increments in otoliths from larval and adult fishes. Fish. Bull. U. S. 74: 1-8

Campana, S. E., Neilson, J. D. (1982). Daily growth increments in otoliths of starry flounder (Platichthys stellatus) and the influence of some environmental variables in their production. Can. J. Fish. aquat. Sci. 39: 937-942

Clarke, M. (1978). Some aspects of the feeding biology of larval walleye pollock, Theragra chalcogramma (Pallas), in the southeastern Bering Sea. M. Sc. thesis, University of Alaska

Cooney, R. T., Coyle, K. O. (1982). Trophic implications of cross-shelf copepod distributions in the southeastern Bering Sea. Mar Biol. 70: 187-196

Cooney, R. T., McRoy, C. P., Nishiyama, T., Niebauer, H. J. (1978). An example of weather influence on marine ecosystem processes. In: McRoy, C. P. (ed.) PROBES: processes and resources of the Bering Sea shelf, Progress Report 1978, Institute of Marine Sciences, University of Alaska, Fairbanks, p. 387-403

Edwards, R. R. C., Steele, J. H., Trevallion, A. (1970). The ecology of 0-group plaice and common dabs in Loch Ewe. III. Prey-predator experiments with plaice. J. exp. mar. Biol. Ecol. 4: 156-173

Geffen, A. J. (1982). Otolith ring deposition in relation to growth rate in herring (Clupea harengus) and turbot (Scophthalmus maximus) larvae. Mar. Biol. 71: 317-326

Hamai, I., Kyushin, K., Kinoshita, T. (1971). Effect of temperature on the body form and mortality in the developmental and early larval stages of the Alaska pollock. Theragra chalcogramma (Pallas). Bull. Fac. Fish. Hokkaido Univ. 22: $11-29$

Hamai, I., Kyushin, K., Kinoshita, T. (1974). On the early larval growth, survival and variations of body form in the walleye pollock, Theragra chalcogramma (Pallas), in rearing experiment feeding the different diets. Bull. Fac. Fish. Hokkaido Univ. 25: 20-35

Haryu, T (1980). Larval distribution of walleye pollock, Theragra chalcogramma (Pallas), in the Bering Sea, with special reference to morphological changes. Bull. Fac. Fish. Hokkaido Univ. 31: 121-136

Iles, T D. (1968). Growth studies on North Sea herring. II. 0 -group growth of East Anglian herring. J. Cons. int. Explor. Mer 31: 98-116

Iverson, R. L., Coachman, L. K., Cooney, R. T., English, T S., Goering, J. J., Hunt, G. L., Jr., Macauley, M. C., McRoy, C. P., Reeburg, W. S., Whitledge, T E. (1979). Ecological significance of fronts in the southeastern Bering Sea. In: Livingston, R. J. (ed.) Ecological processes in coastal and marine systems. Plenum Press, New York, p. 437-466

Ivlev, V. S. (1961). Experimental ecology of the feeding of fishes (transl. by D. Scott). Yale University Press, New Haven

Kinder, T. H., Coachman, L. K. (1978). The front overlaying the continental slope of the eastern Bering Sea. J. geophys. Res. 83: 4551-4559

Kinder, T H., Schumacher, J. D. (1981). Hydrographic structure over the continental shelf of the southeastern Bering Sea. In: Hood, D. W., Calder, J. A. (ed.). The eastern Bering Sea shelf: oceanography and resources, Vol. 1. U.S. Governmental Printing Office, Washington, p. 31-52

Kinne, O. (1960). Growth, food intake, and food conversion in a euryplastic fish exposed to different temperatures and salinities. Physiol. Zool. 33: 288-317

Lasker, R. (1975). Field criteria for survival of anchovy larvae the relation between inshore chlorophyll maximum layers and successful first feeding. Fish. Bull. U. S. 73: 453-461

Laurence, G. C. (1977). A bioenergetic model for the analysis of feeding and survival potential of winter flounder, Pseudopleuronectes americanus, larvae during the period from hatching to metamorphosis. Fish. Bull. U. S. 75: 529-546

Marshall, S. L., Parker, S. S. (1982). Pattern identification in the microstructure of sockeye salmon (Oncorhynchus nerka) otoliths. Can. J. Fish. aquat. Sci. 39: 542-547

McGowan, J. A., Brown, D. M. (1966). A new opening-closing paired zooplankton net. University of California, Scripps Institution of Oceanography, Ref. 66-23

Methot, R. D., Jr., Kramer, D. (1979). Growth of northern anchovy, Engraulis mordax, larvae in the sea. Fish. Bull. U. S. 77: 413-423

Niebauer, H. J. (1980). Sea ice and temperature variability in the eastern Bering Sea and the relation to atmospheric fluctuations. J. geophys. Res. 85: 7507-7515

Okada, K. (1978). Preliminary report of acoustic survey and mid-water trawl on pollock stock in the Aleutian Basin and adjacent waters in summer of 1978 (Jap., Engl. summary). Fish. Agency Jap., p. 1-42

Pannella, G. (1971). Fish otoliths: daily growth layers and periodical patterns. Science, Wash., D. C. 173: 1124-1127

Paloheimo, J. E., Dickie, L. M. (1970). Food and growth of fishes. III. Relation among food, body size and growth efficiency. J. Fish. Res. Bd Can. 23: 1209-1248

Radtke, R. L., Waiwood, KG (1980). Otolith formation and body shrinkage due to fixation in larval cod (Gadus morhua). Can. Tech. Rep. Fish. aquat. Sci. No. 929: 1-10

Ralston, S., Miyamoto, G. T. (1983). Analysing the width of daily otolith increments to age the Hawailan snapper, Pristipomoides filamentosus. Fish. Bull. U. S. 81: 523-535

Smith, G. B. (1981). The biology of walleye pollock. In: The eastern Bering Sea shelf: oceanography and resources. Vol. 1 U. S. Governmental Printing Office, Washington, p. $527-551$

Smith, P. E., Richardson, S. L. (1977). Standard techniques for pelagic fish egg and larvae surveys. FAO Fish. Tech. Pap. 175: $1-100$

Waldron, K. D. (1981). Ichthyoplankton. In: Hood, D. W., Calder, J. A. (ed.) The eastern Bering Sea shelf: oceanography and resources. Vol. 1 U. S. Governmental Printing Office, Washington, p. 471-493

Yusa, T. (1954). On the normal development of the fish. Theragra chalcogramma (Pallas), Alaska pollock. Bull. Hokkaido Reg. Fish. Res. Lab. 10: 1-15, Plates I-VII 